\title{
Lichen flora of Žumberak-Samoborsko gorje Nature Park, NW Croatia
}

\author{
ANAMARIJA PARTL \\ State Institute for Nature Protection, Trg Mažuranića 5, HR 10000 Zagreb, Croatia \\ During 2007 and 2008 epiphytic and terrestrial lichen communities were surveyed in the \\ Žumberak-Samoborsko gorje Nature Park (NW Croatia); 84 taxa were recorded includ- \\ ing, Lecanora thysanophora, which was new to Croatia, and four, Bryoria fuscescens, \\ Lobaria pulmonaria, Usnea subfloridana and Usnea hirta, which are red data species in \\ Croatia.
}

Keywords: Lichen, check list, Žumberak, Samoborsko gorje, Croatia

\section{Introduction}

Most research into lichens in Croatia was done in the late $19^{\text {th }}$ and the first part of the $20^{\text {th }}$ century, and summarised in KUŠAN (1953). Few works were published until the 1990s after recommendations for lichenological research were made (CHRISTENSEN 1987, 1988; Christensen and Hansen 1994; OzimeC 2000; Partl and Asta 2003; Ozimec et al 2009). In 2007 the first check list and red list of Croatian lichens were published, later revised in 2009 (OzIMEC and PARTL 2009a, b). The distribution of most species in Croatia is still not well known. This paper is an attempt to contribute to a broader understanding of lichen flora in the north Croatian mountain region. This area had previously been visited once before (KUŠAN 1928), resulting in the recording of 67, mostly saxicolous, taxa.

\section{Study area}

The lichen survey was carried out in the Žumberak-Samoborsko gorje Nature Park. This is situated in NW Croatia, on the border with Slovenia. It includes parts of Žumberačko and Samoborsko gorje mountains, between the rivers Sava and Kupa, in Croatia, and the river Krka in Slovenia. Altitudes range from 180m in the Kupa river valley increasing to $1178 \mathrm{~m}$ at the summit of Sveta Gera, which is the highest peak of Žumberačko gorje mountain range. In this paper, previous lichen records for the mountains are also mentioned, and all the localities visited are marked on the enclosed map (Fig.1).

\footnotetext{
* Corresponding address, e-mail: anamarija.partl@dzzp.hr

Copyright $^{\circledR} 2011$ by Acta Botanica Croatica, the Faculty of Science, University of Zagreb. All rights reserved.
} 


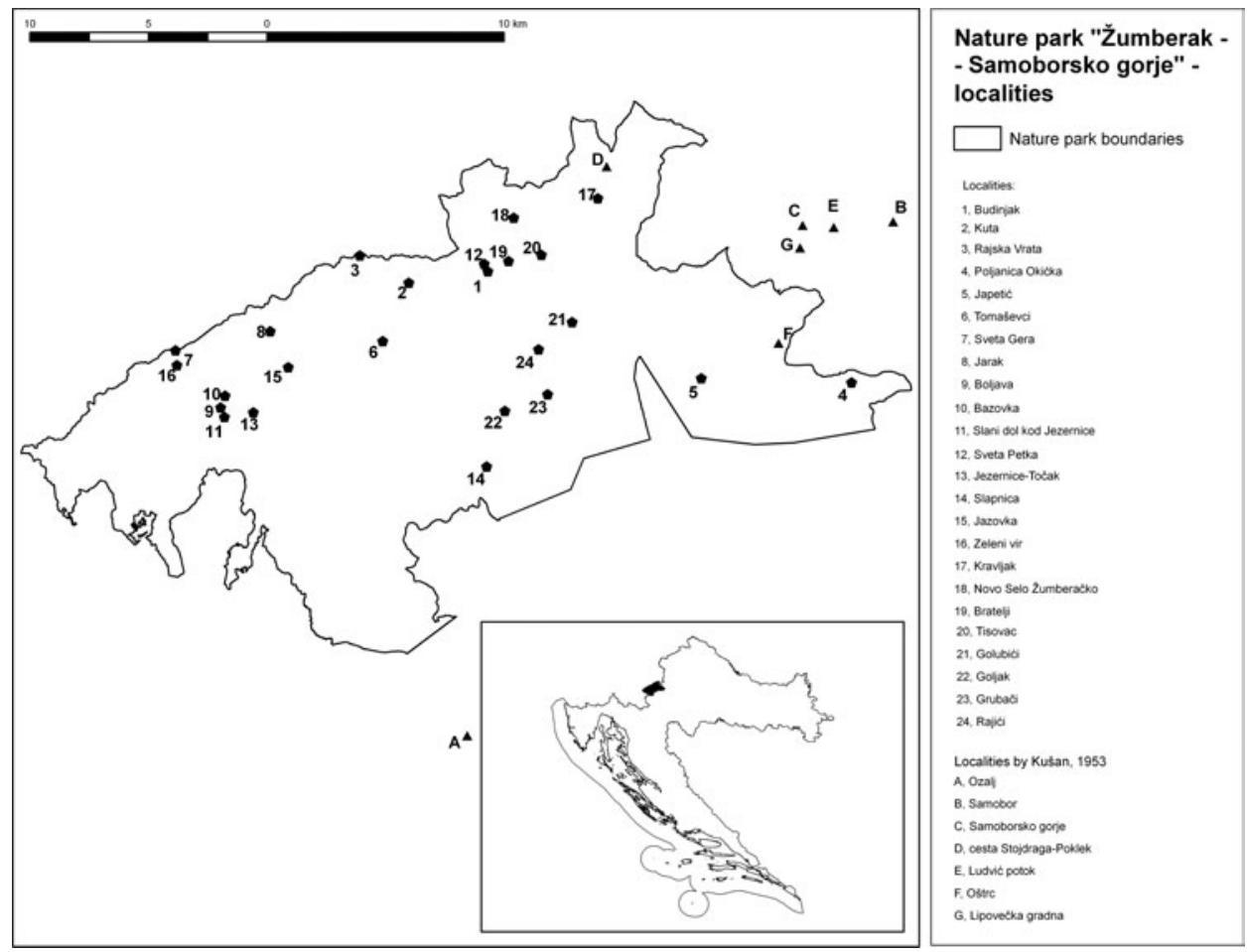

Fig. 1: Map of the study area in Croatia with sampling sites.

Most rock exposures are limestone and dolomites that weather to form a karst landscape. Locally, other rock type outcrops are present, such as sandstone and clay, whilst magmatic rocks can be found in the southeast part of the park. Over three hundred freshwater springs are recorded in the region and most of the permanent streams run in rather deep valleys.

Climate is moderate-continental, with a Mediterranean influence. Average annual temperature is from $7-10^{\circ} \mathrm{C}$, and average annual precipitation in the region exceeds $1100 \mathrm{~mm}$, and may reach $1300 \mathrm{~mm}$ in the highest parts.

The area is mostly covered with forests in which the major types are beech (Fagus silvatica) forests, and, in the lower parts, oak (Quercus spp) and hornbeam (Carpinus betulus) forests. Semi-natural and anthropogenic habitats include planted conifers, old orchards, and meadows.

\section{Materials and methods}

The lichens found during this survey were collected from 24 sites (Fig. 1). Old records, referenced by toponyms (KUŠAN 1928, 1953), were grouped and recorded from 7 additional sites. These should be considered as approximate locations as in the original studies the records were from quite wide areas. Stations indicated by numbers were those examined in this research; old records by KUŠAN (1928) are indicated by letters. 
Lichens were collected in paper bags labelled with site number and substratum. After drying, specimens were identified using both stereo and compound microscopes, and by chemical spot tests. Several keys were used (ClauZAde and Roux 1985, Dobson 1992, PURVIS et al 1992, WIRTH 1995). Nomenclature mostly follows NIMS and MARTELLOS (2008).

\section{Results}

Lichen taxa recorded in this survey, together with older records, are listed alphabetically (Tab. 1), showing stations where they were found. In the present research done during 2007 and 2008, 84 taxa were recorded; previous research from 1928 recorded 67 taxa. Only 10 taxa from 1928 were re-discovered during the present survey. This is probably due to the focus of the earlier survey being on saxicolous lichens, whilst this study concentrated on epiphytic and terrestrial taxa. In further analyses, only taxa recorded in this research were used, as old records could not be properly geo-referenced or verified.

Tab. 1: Lichens from Žumberak-Samoborsko gorje National Park

\begin{tabular}{|c|c|}
\hline SPECIES & STATIONS \\
\hline Amandinea punctata (Hoffm.) Coppins et Scheid. & $2,6,7,8$ \\
\hline Anaptychia ciliaris (L.) Körb. & 7 \\
\hline Arthonia spadicea Leight. & $\mathrm{E}$ \\
\hline Aspicilia calcarea $($ L.) Mudd & G \\
\hline Bacidia bagliettoana (A.Massal. et De Not.) Jatta & $\mathrm{E}$ \\
\hline Baeomyces rufus (Huds.) Rebent. & $\mathrm{C}$ \\
\hline Bagliettoa limborioides A.Massal. & $\mathrm{C}$ \\
\hline Bagliettoa parmigera (J.Steiner) Vìzda et Poelt & $\mathrm{D}$ \\
\hline Bilimbia sabuletorum (Schreb.) Arnold & $\mathrm{E}$ \\
\hline Bryoria fuscescens (Gyeln.) Brodo et D. Hawksw. & $1,19,21,23$ \\
\hline Buellia leptocline (Flot.) A. Massal. & $\mathrm{E}$ \\
\hline Caloplaca cerinella (Nyl.) Flagey & 7 \\
\hline Caloplaca ferruginea (Huds.) Th. Fr. & 7 \\
\hline $\begin{array}{l}\text { Caloplaca flavovirescens (Wulfen) Dalla Torre et } \\
\text { Sarnth. }\end{array}$ & $\mathrm{C}$ \\
\hline Caloplaca holocarpa (Ach.) A. E. Wade & 18,19 \\
\hline Candelaria concolor (Dicks.) Stein & 12 \\
\hline Candelariella reflexa (Nyl.) Lettau & 10 \\
\hline Candelariella vitellina (Hoffm.) Müll. Arg. & $\mathrm{E}$ \\
\hline Candelariella xanthostigma (Ach.) Lettau & $1,2,4,7,10,12,17,18,19,21$ \\
\hline Catillaria lenticularis (Ach.) Th. Fr. & $\mathrm{C}$ \\
\hline Cetrelia olivetorum (Nyl.) W. L. Culb. et C. F. Culb. & $4,5,7,12$ \\
\hline Cladonia caespiticia (Pers.) Flörke & $\mathrm{C}$ \\
\hline Cladonia coniocraea (Flörke) Spreng. & $1,10, \mathrm{E}, \mathrm{G}$ \\
\hline
\end{tabular}


PARTL A.

Tab. 1 - continued

\begin{tabular}{|c|c|}
\hline SPECIES & STATIONS \\
\hline Cladonia digitata (L.) Hoffm. & $\mathrm{E}, \mathrm{G}$ \\
\hline Cladonia fimbriata (L.) Fr. & $1, \mathrm{G}$ \\
\hline Cladonia furcata (Huds.) Schrad. & $\mathrm{E}, \mathrm{G}$ \\
\hline Cladonia macilenta Hoffm. subsp. macilenta & $\mathrm{C}$ \\
\hline Cladonia pyxidata (L.) Hoffm. & $15, \mathrm{C}, \mathrm{E}, \mathrm{F}$ \\
\hline Cladonia rangiferina (L.) F. H. Wigg. & $\mathrm{C}, \mathrm{G}$ \\
\hline Cladonia rangiformis Hoffm. & $\mathrm{F}$ \\
\hline Cladonia squamosa Hoffm. var. squamosa & $\mathrm{E}, \mathrm{G}$ \\
\hline Clauzadea monticola (Schaer.) Hafellner et Bellem. & $\mathrm{D}$ \\
\hline Collema flaccidum (Ach.) Ach. & 2,13 \\
\hline Collema fuscovirens (With.) J. R. Laundon & 13 \\
\hline Collema tenax (Sw.) Ach. & $\mathrm{E}, \mathrm{F}$ \\
\hline Dermatocarpon intestiniforme (Körb.) Hasse & $\mathrm{D}$ \\
\hline Dermatocarpon miniatum (L.) W. Mann & $13, \mathrm{~A}$ \\
\hline Dibaeis baeomyces (L.) Rambold et Hertel & $\mathrm{D}$ \\
\hline Diploschistes muscorum (Scop.) R. Sant. & $\mathrm{E}$ \\
\hline Diplotomma alboatrum (Hoffm.) Flot. & G \\
\hline Evernia prunastri (L.) Ach. & $1,2,7,12,17,18,20,21,22,23,24$ \\
\hline Farnoldia jurana (Schaer.) Hertel subsp. jurana & $\mathrm{E}$ \\
\hline Flavoparmelia caperata (L.) Hale & $1,4,6,8,10,18,19,20,22,24, \mathrm{E}$ \\
\hline Fuscidea stiriaca (A.Massal.) Hafellner & $8, \mathrm{E}$ \\
\hline Graphis scripta (L.) Ach. & $2,4,8,10, \mathrm{~B}$ \\
\hline Gyalecta hypoleuca (Ach.) Zahlbr. & $\mathrm{E}$ \\
\hline Gyalecta jenensis (Batsch) Zahlbr. & $\mathrm{C}$ \\
\hline Hypocenomyce scalaris (Ach.) M. Choisy & 1 \\
\hline Hypogymnia physodes (L.) Nyl. & $1,3,7,10,12,17,18,19,20,21,22,24$ \\
\hline Hypogymnia tubulosa (Schaer.) Havar. & $1,7,10,12,17,18,19,20,21,23$ \\
\hline Lecanora allophana Nyl. & $2,7,10$ \\
\hline Lecanora argentata (Ach.) Malme & 7,10 \\
\hline Lecanora carpinea (L.) Vain. & $10,12,18$ \\
\hline Lecanora chlarotera $\mathrm{Nyl}$. & $1,2,3,4,5,7,8,9,10,11,12,17$ \\
\hline Lecanora conizaeoides Cromb. & 4 \\
\hline Lecanora dispersa (Pers.) Sommerf. & $\mathrm{D}$ \\
\hline Lecanora expallens Ach. & 7 \\
\hline Lecanora leptyrodes (Nyl.) Degel. & 4,9 \\
\hline Lecanora thysanophora R. C. Harris & 10 \\
\hline widctlparLecanora saligna (Schrad.) Zahlbr. & 1,10 \\
\hline Lecidella elaeochroma (Ach.) M. Choisy & $1,2,4,5,7,8,10,11,20$ \\
\hline Lepraria nivalis J. R. Laundon & 5 \\
\hline Leptogium lichenoides (L.) Zahlbr. & $\mathrm{B}$ \\
\hline
\end{tabular}


Tab. 1 - continued

\begin{tabular}{|c|c|}
\hline SPECIES & STATIONS \\
\hline Leptogium saturninum (Dicks.) Nyl. & 2,14 \\
\hline Lobaria pulmonaria (L.) Hoffm. & $2,7,10, \mathrm{C}$ \\
\hline Melanelia elegantula (Zahlbr.) Essl. & 7 \\
\hline Melanelia exasperata (De Not.) Essl. & $1,7,18,10,21$ \\
\hline Melanelia exasperatula (Nyl.) Essl. & 6 \\
\hline Melanelia fuliginosa (Duby) Essl. subsp. glabratula & $\begin{array}{l}1,2,4,5,7,8,10,14,17,18,19,20,22, \\
23,24\end{array}$ \\
\hline Melanelia glabra (Schar.) Essl. & 1 \\
\hline Melanelia subaurifera (Nyl.) Essl. & $2,7,10,12$ \\
\hline Menegazzia terebrata (Hoffm.) A. Massal. & $\mathrm{E}$ \\
\hline Micarea peliocarpa (Anzi) Coppins et R. Sant. & G \\
\hline Mycobilimbia lurida (Ach.) Hafellner et Türk & $\mathrm{F}$ \\
\hline Ochrolechia turneri (Sm.) Hasselrot & 5,7 \\
\hline Opegrapha calcarea $\mathrm{Sm}$. & $\mathrm{D}$ \\
\hline Opegrapha rupestris Pers. & $\mathrm{D}, \mathrm{E}$ \\
\hline Parmelia omphalodes (L.) Ach. & $\mathrm{G}$ \\
\hline Parmelia saxatilis (L.) Ach. & $1,2,4,7,10$ \\
\hline Parmelia sulcata Taylor & $\begin{array}{l}1,2,4,6,7,8,9,10,12,17,18,18,20 \\
21,24\end{array}$ \\
\hline Parmelina pastillifera (Harm.) Hale & $4,6,7,10$ \\
\hline Parmelina quercina (Willd.) Hale & 18 \\
\hline Parmelina tiliacea (Hoffm.) Hale & $\begin{array}{l}1,2,4,6,7,8,17,18,19,20,21,22,23, \\
24\end{array}$ \\
\hline Parmeliopsis ambigua (Wulfen) Nyl. & $1,3,10$ \\
\hline Parmotrema crinitum (Ach.) M. Choisy & $\mathrm{G}$ \\
\hline Parmotrema perlatum (Huds.) M. Choisy & $7,10,14$ \\
\hline Peltigera canina (L.) Willd. & $\mathrm{E}$ \\
\hline Peltigera didactyla (With.) J. R. Laundon & 16 \\
\hline Peltigera horizontalis (Huds.) Baumg. & $2,15, \mathrm{G}$ \\
\hline Peltigera membranacea (Ach.) Nyl. & 2 \\
\hline Peltigera polydactyla (Neck.) Hoffm. & $2,10,13,16$ \\
\hline Peltigera praetextata (Sommerf.) Zopf & $14,15,16, \mathrm{E}$ \\
\hline Peltigera rufescens (Weiss) Humb. & 2 \\
\hline Peltigera venosa (L.) Hoffm. & $\mathrm{D}$ \\
\hline Pertusaria albescens (Huds.) M. Choisy et Werner & $2,4,7,10,22$ \\
\hline Pertusaria amara (Ach.) Nyl. & 7,22 \\
\hline Pertusaria coccodes (Ach.) Nyl. & 7,10 \\
\hline Pertusaria corallina (L.) Arnold & G \\
\hline Pertusaria flavida (DC.) J. R. Laundon & 20 \\
\hline Pertusaria leioplaca DC. & $\mathrm{E}$ \\
\hline
\end{tabular}


PARTL A.

Tab. 1 - continued

\begin{tabular}{|c|c|}
\hline SPECIES & STATIONS \\
\hline Pertusaria pertusa (Weigel) Tuck. & $2,4,5,7,8,10$ \\
\hline Phaeophyscia orbicularis (Neck.) Moberg & $1,7,18$ \\
\hline Phlyctis argena (Spreng.) Flot. & 4,7 \\
\hline Physcia adscendens (Fr.) H. Olivier & 2,7 \\
\hline Physcia stellaris (L.) Nyl. & $1,3,7,12,18,19,20,21,23$ \\
\hline Physcia tenella (Scop.) DC. & $1,5,7,18,21$ \\
\hline Physcia tribacia (Ach.) Nyl. & 7 \\
\hline Physconia distorta (With.) J. R. Laundon & 1 \\
\hline Physconia grisea (Lam.) Poelt subsp. grisea & 7 \\
\hline Physconia perisidiosa (Erichsen) Moberg & 1,2 \\
\hline Placynthium nigrum (Huds.) Gray & $\mathrm{D}$ \\
\hline Platismatia glauca (L.) W. L. Culb. et C. F. Culb. & $1,7,10,19,21,24$ \\
\hline Pleurosticta acetabulum (Neck.) Elix et Lumbsch & 7 \\
\hline Porina lectissima (Fr.) Zahlbr. & $\mathrm{C}$ \\
\hline Porpidia albocaerulescens (Wulfen) Hertel et Knoph & $\mathrm{C}$ \\
\hline Porpidia crustulata (Ach.) Hertel et Knoph & $\mathrm{D}$ \\
\hline Porpidia macrocarpa (DC.) Hertel et A. J. Schwab & $\mathrm{E}$ \\
\hline Protoblastenia rupestris (Scop.) J. Steiner & $\mathrm{D}$ \\
\hline Pseudevernia furfuracea (L.) Zopf var. furfuracea & $1,7,10,12,17,18,19,20,21,24$ \\
\hline Punctelia subrudecta (Nyl.) Krog & 2 \\
\hline Ramalina calicaris (L.) Fr. & 7,9 \\
\hline Ramalina farinacea (L.) Ach. & $1,2,4,6,7,9,10$ \\
\hline Ramalina fastigiata (Pers.) Ach. & 7,20 \\
\hline Ramalina fraxinea (L.) Ach. & $1,2,7,8$ \\
\hline Rhizocarpon reductum Th. Fr. & $\mathrm{E}$ \\
\hline Rinodina confragosa (Ach.) Körb. & $\mathrm{E}$ \\
\hline Rinodina oxydata (A.Massal.) A. Massal. & $\mathrm{E}$ \\
\hline Sarcogyne regularis Körb. var. regularis & $\mathrm{D}$ \\
\hline Solorina saccata (L.) Ach. & $\mathrm{D}, \mathrm{F}$ \\
\hline Usnea hirta (L.) F. H. Wigg. & 1,12 \\
\hline Usnea subfloridana Stirt. & $1,7,10,12,17,18,19,20,21,22,23,24$ \\
\hline Verrucaria margacea (Wahlenb.) Wahlenb. & $\mathrm{E}$ \\
\hline Verrucaria muralis Ach. & $\mathrm{D}$ \\
\hline Verrucaria nigrescens Pers. & $\mathrm{C}$ \\
\hline Verrucaria saprophila (A. Massal.) Trevis. & $\mathrm{D}$ \\
\hline Vulpicida pinastri (Scop.) J.-E. Mattsson & 1,19 \\
\hline Xanthoparmelia conspersa (Ach.) Hale & $\mathrm{E}$ \\
\hline Xanthoria candelaria (L.) Th. Fr. & 12,18 \\
\hline Xanthoria parietina (L.) Th. Fr. & $1,3,7,12,18,19,20,21,23,24, \mathrm{C}$ \\
\hline Xanthoria polycarpa (Hoffm.) Rieber & $7,19,21$ \\
\hline
\end{tabular}




\section{Discussion}

Lecanora thysanophora is the first Croatian record for this species, and out of 84 taxa recorded during the survey 74 are new records for the area.

Most lichens were epiphytes on birch (Betula pendula), oak (Quercus sp.) and, at the higher altitudes, beech (Fagus silvatica). Of particular importance as porophytes were veteran fruit trees in grassland orchards and planted larch trees at location 12.

Foliose lichens were the most abundant (42 species), followed by crustose taxa (23) and then fruticose lichens (13). Other growth forms were not common, and comprised three composite taxa (Cladonia type), two leprose, and one squamose lichen.

The most important habitats for lichens were open forests, old orchards, and old forests undisturbed by forestry management.

In terms of response to light intensity, most of the species recorded preferred well lit situations but were also able to tolerate shade. Orchards and open forests were the favoured habitats for such species. No extreme skiophytes were found, and very few species requiring direct solar irradiation. Species recorded from old forests favoured semi-shaded to shaded habitats.

As regards temperature tolerance, most of the lichens recorded were those favouring submontane to montane regions, which is consistent with the climate and terrain in the area. Extremely thermophilous lichens were not recorded. Tolerance to cold is a survival factor for a few montane to high montane species, such as Bryoria fuscescens, Cetrelia olivetorum, Hypogymnia tubulosa, Melanelia exasperata, Parmeliopsis ambigua, Platismatia glauca and Usnea subfloridana and one highmontane to subalpine species - Vulpicida pinastri, which inhabited valleys where cold air persists, or snow lays for longer periods.

Oceanity shows the tolerance of lichens to extreme climate changes during the yearoceanic species prefer milder climate with fewer variations and are more common in Western Europe: such are the most numerous in the region if we exclude species that are widespread. No continental species were found, which suggests the climate is mild continental with no extremes.

No extreme hygrophytes nor xerophytes were found - the $1000 \mathrm{~mm}$ yearly precipitation experienced by the area being sufficient to satisfy the water requirements of the species recorded.

Lichens are sensitive to $\mathrm{pH}$ and the substrata, which makes them good indicators of environmental quality. A number of species are epiphytes on certain tree types. Many species in this area grow on mildly acid substrata, but a few are able to tolerate more acid conditions: they can either tolerate pollution resulting from acid rain or prefer trees with more acid bark such as conifers and birch (which is the case in the study area).

For epiphytic lichens a further limiting factor is the nutrition value of the substratum. Some tree species have higher concentrations of important minerals in bark than others, such as ash (Fraxinus excelsior) and maples (Acer sp.) An absence of epiphytes on trees does not therefore necessarily indicate environmental pollution. Most of the lichens found in the study area were epiphytes on trees that indicated low nutrition requirements, with a smaller number (presumably requiring a higher mineral requirement) found on naturally richer bark. A number of species were usually recorded from the base of trees, where 
eutrophication is caused by animal excrements or by exhaust gases of vehicles at the roadsides.

Because of their sensitivity to certain anthropogenic chemicals lichens have long been used as indicators of environmental pollution. The presence of toxitolerant species does not necessarily signify pollution, but the appearance of sensitive taxa is a good signal. In the study area most of the species recorded a fall somewhere in the middle of the scale of tolerance; three species extremely sensitive to environmental pollution-Leptogium saturninum, Lobaria pulmonaria and Melanelia exasperata - and another 12 moderately sensitive taxa were recorded. This indicates that the area has experienced excellent air quality over a long time period. Lobaria pulmonaria, which is an old forest indicator, was found in several localities, showing that this area has remained undisturbed or minimally managed for some considerable time a factor that makes its protection of significant importance. To summarise; the presence of old forest indicators, together with species sensitive to environmental pollution indicates that this area should be protected.

Old orchards within the study area, in which agro chemicals have never been used, support high numbers of otherwise rare and sensitive species, including Usnea subfloridana, $U$. hirta and Bryoria fuscescens, which makes their continued, traditional management as grassland orchards of vital importance. Some areas shown a high number of interesting species, and should be protected as special reserves: Budinjak is a still a thriving village, and the nearby birch and oak forest, that have been minimally managed, should be conserved. In particular the locations where Lobaria pulmonaria was found, especially areas near the peak on the Slovenian border, should be protected as special forest reserves and left unmanaged or managed minimally. This lichen does not survive intensive commercial forestry, particularly when growing outside its normal oceanic climate range (which is the case within the Park). A number of rare species have been recorded near the summit in Slovenia, in two special forest reserves, Trdinov vrh and Ravna gora (HočEVAR 1985).

Any future study should be performed in terms of various environmental factors, such as light requirements, temperature, oceanity, water requirements, $\mathrm{pH}$ and nutrition values of the substratum and toxitolerance, and should also compare relationships with other studies (WIRTH 1992).

\section{Acknowledgements}

I would like to thank Prof. Helmut Mayrhofer (Austria) for doing the TLC analysis and determination of leprose lichens, Ivan Pedley (England) for help with determination of some samples and English language revision, Prof. Franc Batič (Slovenia) for providing me needed literature, and Dr. Matija Franković (Croatia) who accompanied me in most of my fieldwork in Žumberak - Samoborsko gorje Nature Park and provided information on the location of lichen rich habitats. 


\section{References}

Christensen, S. N., 1987: Contribution to the lichen flora of Yugoslavia. Acta Botanica Croatica 46,161-171.

Christensen, S. N., 1988: Contribution to the lichen flora of Istria, Yugoslavia. Acta Botanica Croatica 47,127-134.

Christensen, S. N., Hansen, E. S., 1994: Lichens from Croatia. Acta Botanica Croatica $53,101-113$.

Clauzade, G., Roux, C., 1985: Lichens of the Western Europe (in Esperanto). Bulletin de la Societe Botanique du Centre-Ouest, Nouvelle Serie, No. Special 7, 1-893.

Dobson, F. S., 1992: Lichens. An illustrated guide to the British and Irish species. Richmond Publishing, Slough.

HoČEVAR, S., 1985: Dinaric old montane forests (in Slovenian). Strokovna in znanstvena dela 76, 7-262.

KušAn, F., 1928: Contribution to the lichen flora of Croatia (in Croatian). Acta Botanica Instituti Botanici Universitatis Zagrebensis 3, 1-40.

KušAN, F., 1953: Lichen check list of Yugoslavia (in Croatian). Jugoslavenska akademija znanosti i umjetnosti, Zagreb.

Nims, P. L., Martellos, S., 2008: ITALIC - The information system on Italian lichens. Version 4.0. Univesity of Trieste, Department of Biology, IN4.0/1. (http://dbiodbs. univ.trieste.it/)

OzIMEC, S., 2000: Five new lichen species to the Croatian flora. Natura Croatica 9, 133-138.

Ozimec, S., FloRIJANČIĆ, T., OpaČAK, A., PušKAdIJA, Z., Topić, J., 2009: Lichen mycota from the island of Krk (northern Adriatic Sea, Croatia). Natura Croatica 18, 367-385.

OzimeC, S., PARTL, A., 2009a: Red list of lichens of Croatia (in Croatian). Državni zavod za zaštitu prirode, Zagreb.

Ozimec, S., PARTL, A., 2009b: Check list of lichens of Croatia (in Croatian). Državni zavod za zaštitu prirode, Zagreb.

PARTL, A., AstA, J., 2003: Epiphytic lichen flora on mountain Medvednica and in northern Zagreb: bioindication of environmental factors. Periodicum Biologorum 105, 337-343.

Purvis, O. W., Coppins, B. J., Hawksworth, D. L., James, P. W., Moore, D., 1992: The lichen flora of Great Britain and Ireland. Natural History Museum Publications in association with The British Lichen Society, London.

WIRTH, V., 1992: Bioindication values of lichens (in German). Scripta Geobotanica 18, 215-237.

WIRTH, V., 1995: Flechten aus Baden Wuerttenberg, 1-2. Ulmer, Stuttgart. 